\title{
アーチ型床止め工の水理機能に関する実験的研究 \\ Experimental Study of Hydraulic Functions of Arched Weirs
}

\author{
藤田一郎 ${ }^{*} \cdot$ 河村三郎 ${ }^{* *} \cdot$ 神田徹 ${ }^{* * *} \cdot$ 梅村裕也 ${ }^{* * * *}$ \\ By Ichiro FUJTA, Saburo KOMURA, Toru KANDA and Hiroya UMEMURA
}

\begin{abstract}
Effects of the plane shape of a weir on the downstream flow structures are experimentally examined. Arched weirs having different curvatures, an arched one set in reverse direction and a straight type weir, are used for experimental study. Mean and turbulent velocity distributions and shear stress distributions are measured in the downstream region of each weir. It is found that arched weirs converge the flow to the center portion of the channel, while a reversearched type diverges the main stream to the side portions of the channel. Deduced structures of the flows are also presented.
\end{abstract}

Keywords:hydraulic structure, weir, open-channel flow, ground sill

\section{1. 序論}

近年, 河川工学においても環境あるいは景観に対する配虑が重要視され，自然材料を組み合わせた河川構 造物や魚類を意識した護床ブロックなどが採用されるようになってきた。多くの自治体においても，このよ うな多自然型河川工法を取り入れて水辺を中心とした地域づくりが進められるようになってきた。一方，中 小河川などに古くから設置されている床止め工は，河川を横断して設けられる大型の河川構造物であり河川 景観にも大きな影䍩を与えている。またこれによって生じる流況も景観や生態系を構成する重要な要因の 1 つと考えられる。特に，河川中流部における床止め工周辺は，水遊びや休䄭の場などとして親水活動の拠 点”となっている。しかしながら, 大部分は河川を直線的に横断する単純な形状をしており, 景観面などか ら言えば必ずしも十分な工夫がなされているとは考えにくいのが現状と思われる。

そこで, 本研究では床止め工の平面形状を変化させることにより景観を向上させることができないかと考 え, 従来, 下流の流心を河川中央に集めることはできるが，下流における深掘れが生じやすい2)などとして， あまり採用されなかったアーチ型の床止め工を見直し，その水理学的機能にっいて再検討することとした。 本研究では, 床止め工の平面形状の変化が下流の平均的な流れ場に与える影響について定量的に把握するこ

\begin{tabular}{|c|c|c|c|c|c|}
\hline 正会員 & 学術博 & 岐阜大学助教授 & 工学部土木工学科 & ( $\bar{T} 501-11$ & 岐阜県岐阜市柳戸1-1） \\
\hline 正会 & 工博 & 岐阜大学教授 & 工学部土木工学科 & ( & 同上 ） \\
\hline & 工博 & 神戸大学教授 & 工学部土木工学科 & ( $\bar{T} 657$ ) & 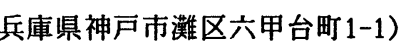 \\
\hline & & 岐阜大学大学院 & 工学研究科土木工学専攻 & $(\bar{\top} 501-11$ & 岐阜県岐阜市柳戸1-1） \\
\hline
\end{tabular}


とを目的とした。

\section{2. 実験概要}

実験は, 図ー 1 に示すような水路 幅 $\mathrm{B}=0.3 \mathrm{~m}$, 水路長 $9 \mathrm{~m}$ のアクリル製循 環水路を使用し，水路勾配を $1 / 1000$

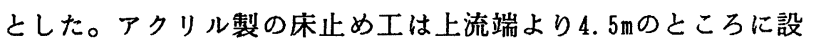
置して実験を行った。本実験で対象とした床止め工の平面形状

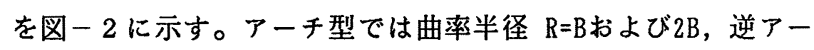
チ型では $\mathrm{R}=\mathrm{B}$ とした。床止め工の落差はd $=0.01 \mathrm{~m}$, 幅祖は $0.05 \mathrm{~m}$ と した（図一 3）。そして, 床止め工設置後十分に堆砂した状態 を想定して,Backstep Typeの実験む行った。これに対し床止め 工を単独で設置したケースをここでは Sil1 Typeと呼ぶことと する。水理条件は, どのケースも流量 $5 \times 10^{-3} \mathrm{~m}^{3} / \mathrm{s}$ とし, 下流水 深は等流水深 $\mathrm{H}=0.05 \mathrm{~m}$ と等しくなるように調整した。本実験で は, 平均流速測定および表面流況之底面流線の可視化を行った。 流速測定は, 床止め工上流側で 1 断面, 下流側で 4 断面の計 5 断面（図-4）で行い，計測には直径 $3 \mathrm{~mm}$ の正逆プロペラ流速計 （篠塚製作所，SV-3W）を用いた。サンプリングは $20 \mathrm{~Hz}$ で40秒 間行い, A / D 変換ボードを組み込んだラップトップ コンピュータにより計測及び出力の統計処理を行 た。表面流況は, 平均粒径 $2 \mathrm{~mm}$ 程度のおがくずをトレき 一サーとして可視化し，水路上方に設置した C C D カメラを通して，V T R に記録した。表面流速は画 像処理システム（P I A S , LA-525) と相関法 ${ }^{3)}$ よって求めた。底面流況の可視化には, $1 / 2$ に薄め た白色のポスターカラーを用い, 水路底面の横断方 向に等間隔で塗り付けた。油膜が十分に伸びた状態 で, 1/60secのシャッタースピードでモノクロ撮影し た。

\section{3. 実験結果と考察}

3. 1 流下方向の流速分布

Sil1 Typeの直線型, アーチ型 $(\mathrm{R}=\mathrm{B})$ および逆アー チ型における流下方向の平均流速分布を図ー5 (a) (b) (c) に示す。摩擦速度U*には下流の等流域におけ る值を用いた。床止め工より上流の断面では，いず れの形状む類似した分布を示しているが, 下流の断 面では明らかに異なることがわかる。断面 $\mathrm{X} / \mathrm{B}=0.5$ で比較すると, アーチ型では直線型に比べ側壁おょ 0.0 び底面付近の流速を低減させるのに対し, 逆アーチ 型では側壁付近の流速を増大させる一方で底面付近
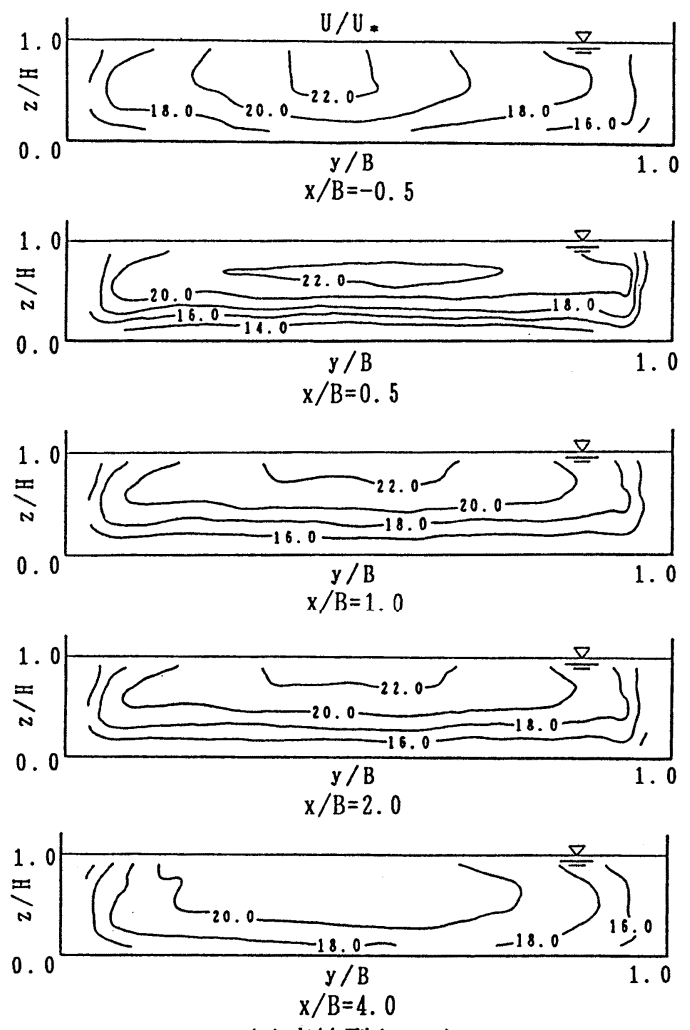

(a) 直線型 (Si11)

図-5 流下方向の平均流速分布 
の流速を著しく減速させていることがわかる。この項向は，さらに下流の断面においてる見られ，特に逆了 一千型では水路中央をはさんで両側に流速の極大值が生じるという特異な分布形が現れている。直線型とア 一千型の差は逆アーチ型との差ほど大きくはないが, $\mathrm{x} / \mathrm{B}=4.0$ においてす, アーチ型による流速集中の効果が 確かに現れていることから，この傾向はさらに下流へる及んでいるすのと思われる。また, Backstep Typeに おけるアーチ型と逆アーチ型を比較したのが図-5(d)(e)である。この場合, Sil1 Typeで見られた逆アーチ 型による特異な分布形は出現しておらず，アーチと逆アーチの差はあまり見られない。これは，床止め工下 流の流況が, 床止め工の上流端の幾何形状に依存していることを示している。即ち, 床止め工がSill Typeの 場合にその上流端で剥離したせん断層の平面形状が，それより下流の流況に著しい影響を及ぼすことがわか る。
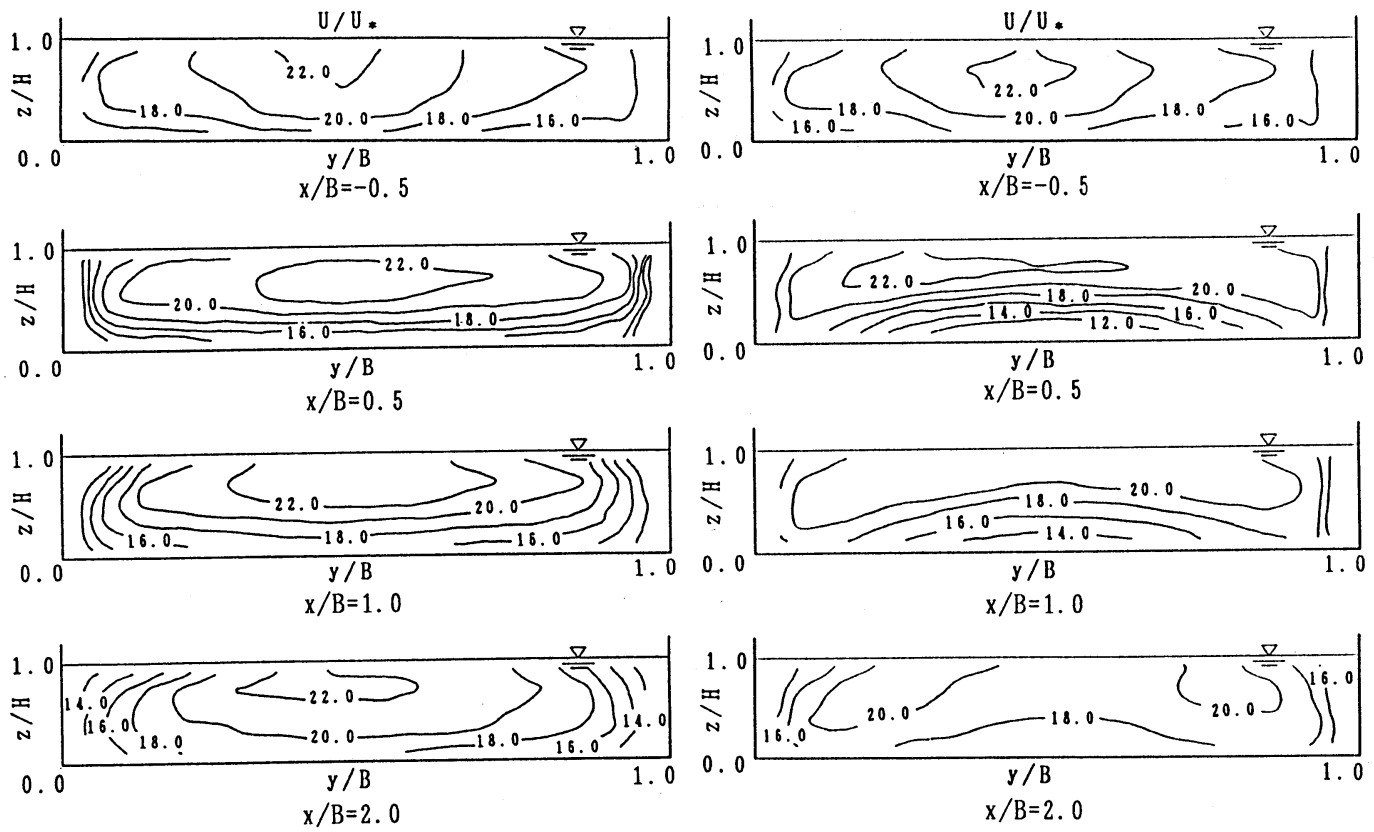

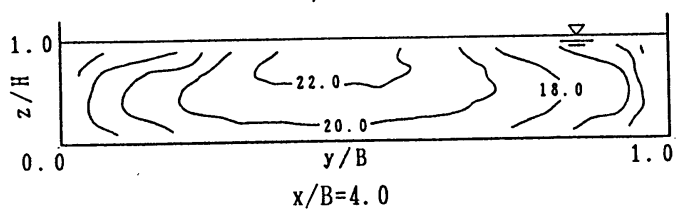

(b) $ア$ チ型 $($ Si11:R=B)
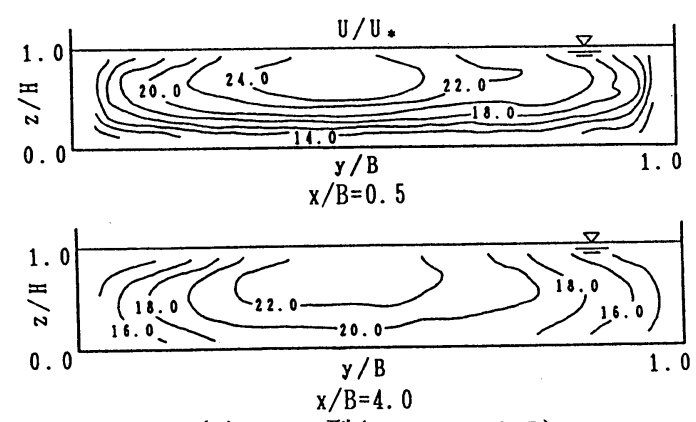

(d) アーチ型 (Backstep:R=B)

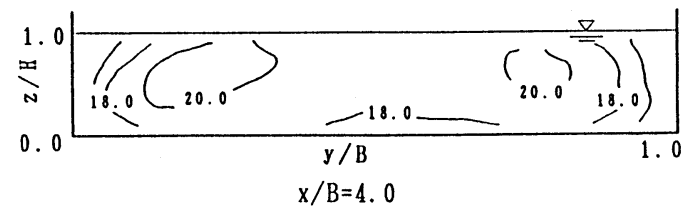

(c)逆アーチ型 (Si11:R=B)
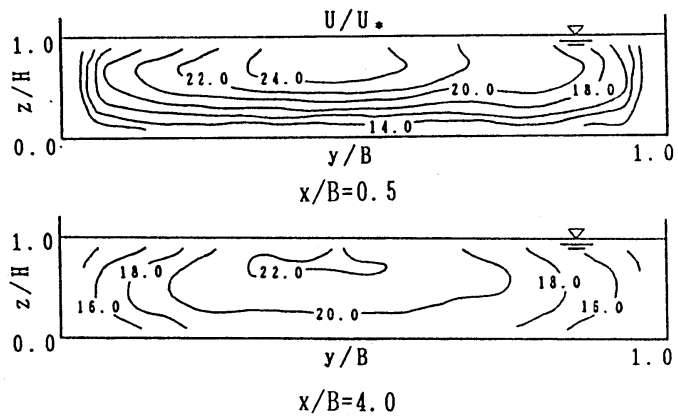

(e)逆アーチ型 (Backstep:R=B)

図- 5 流下方向の平均流速分布 

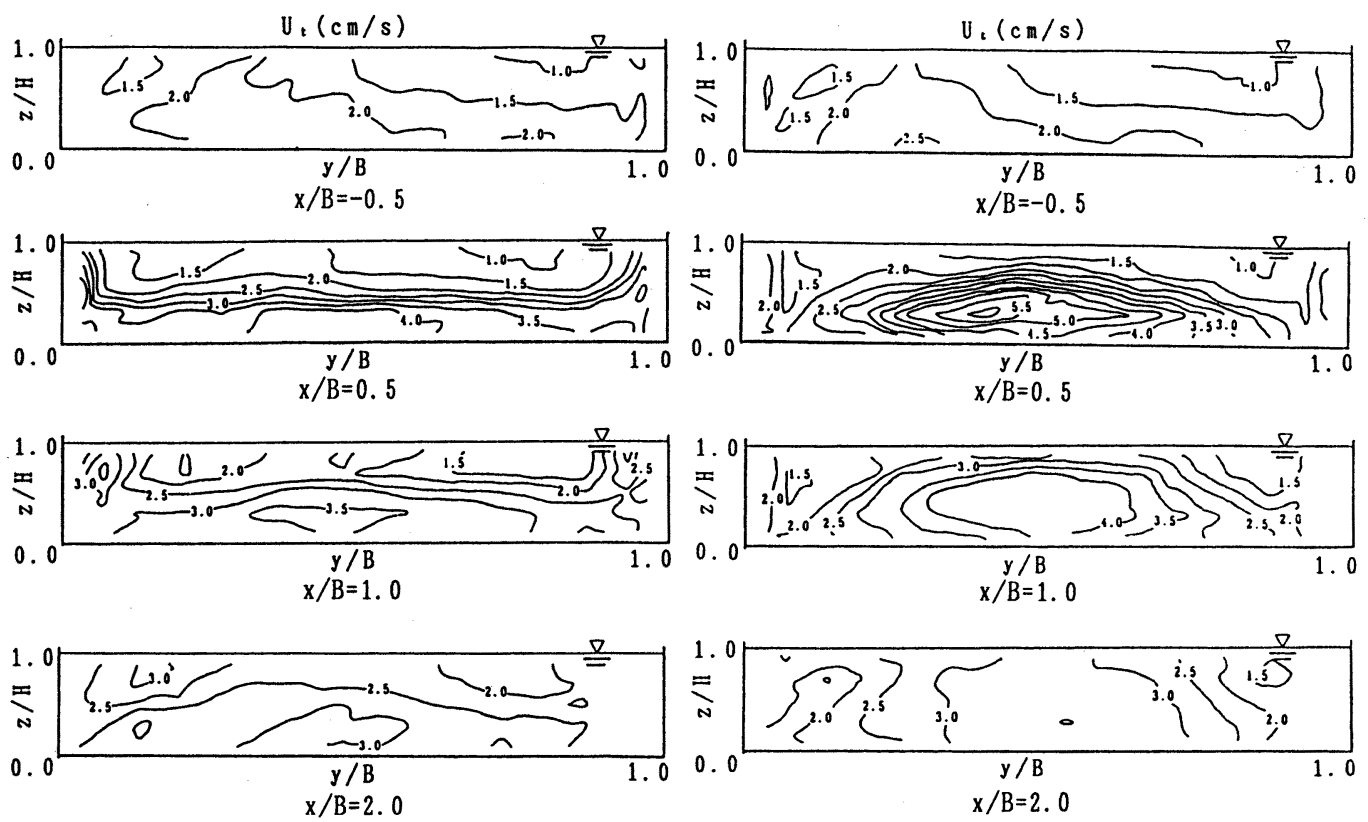

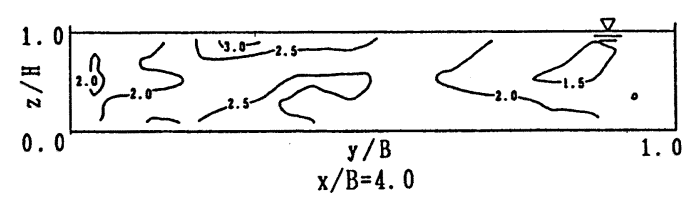

(a) アーチ型 (Si11:R=B)

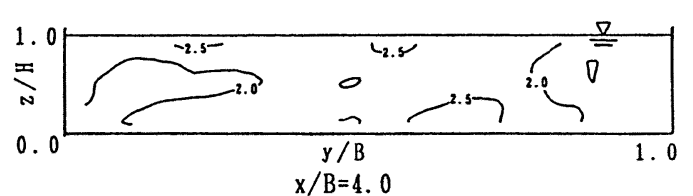

(b) 逆アーチ型 $($ Si 11:R=B)

図-6 流下方向の乱れ強度分布

\section{3 . 2 乱れ強度分布}

図-6にSi11 Typeにおけるアーチ型と逆アーチ型の流下方向の乱れ強度Utの分布を示す。床止め工の形状 による影響が顕著に現れるのは $\mathrm{x} / \mathrm{B}=0.5$ の断面であり,アーチ型では水路中央の底面付近に最大值が生じるの に対し，逆アーチ型では， $z / \mathrm{H}=0.3$ あたりに最大值が生じている。その絶対值す逆アーチ型の方が大きなるの となっており, 水路中央で流速の变動が大きくなっていることがわかる。これらは流れの内部構造の違いに 起因するすのである。即ち，水路中央部でのアーチ型による下降流および逆アーチ型による上昇流の発生を 示唆するすのと考えられる。

\section{3 . 3 表面流速ベクトル}

図ー7に相関法で求めた表面流速べクトルの約10秒 間の平均值を示す。どちらのヶースも床止工付近では 同様に流速が増大しているが，下流においては異なっ た流況を呈している。アーチ型の場合は水路中央に函 大值が生じ，側壁付近で流速が減少しているのに対し， 逆アーチ型では水路中央で極小值が生じるととすに側 壁付近で流速が増大している。この傾向は, 床止工よ りB/2ほど下流から顕著に現れている。このような特 徵は, 前述した流れの内部構造が水表面にまで及んだ 結果生じたすのと考えられる。

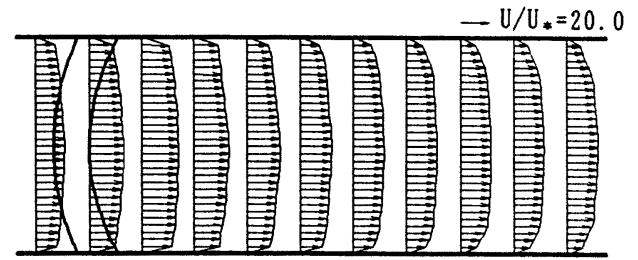

(a) アーチ型 $($ Si11:R=B)

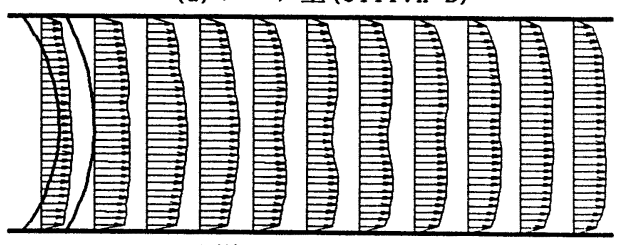

(b) 逆アーチ型 (Si11:R=B)

図一 7 表面流速ベクトル 


\section{4 底面流線}

Sil1 Typeに対して得られた底面流線の可視化パターンを図-8に示す。ただし，この場合は流線のパター ンの差が明確になるように，下流水深を多少增大し $(\mathrm{H}=0.08 \mathrm{~m})$ ，平均流速を減少させて可視化を行っている。 油膜（染料）により生じている白い筋（底面流線）は，底面における平均的なせん断力の方向を示しており， 各ヶースで特徵あるパターンが得られた。まず, 床止め工直下流部に注目すると各々の平面形状に対して底 面における逆流域の形状が著しく異なっていることがわかる。また，下流域においては，アーチ型が水路中 央を境界にして発散傾向, 逆アーチ型が収束傾向を示している。このような特徵すやはり流れの内部構造が 底面流況に波及した結果と考えられる。

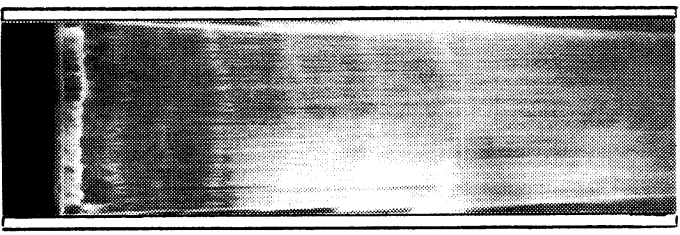

(a) 直線型 (Si 1 1)

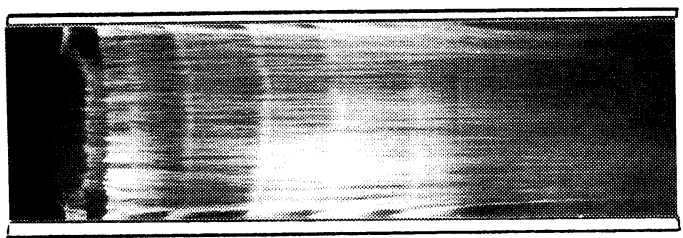

(c) アーチ型 $($ S i 1 1 : R=2B)

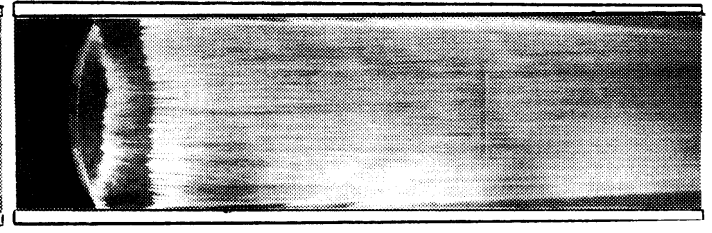

(b) アーチ型 (Si 11:R=B)

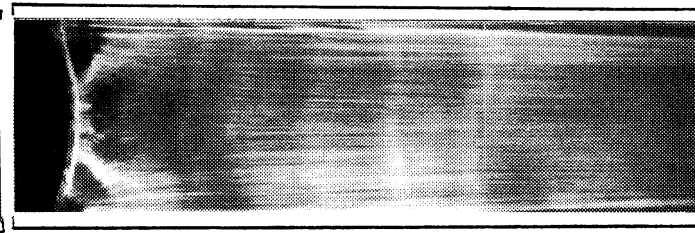

(d) 逆アーチ型 (Si11:R=B)

図-8 底面流線のパターン

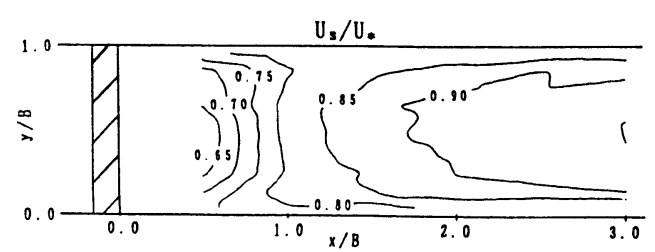

(a) 直線型 (Si 1 1 )

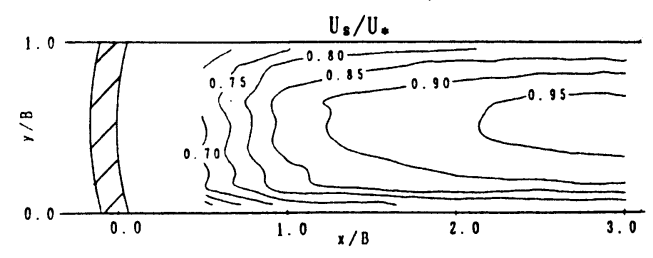

(c) アーチ型 $($ S i 11:R=2B $)$

\section{5 底面せん断力分布}

各ケースにおける底面せん断力の分布を図ー 9 (a)〜 (d) に示す。底面摩擦速度Usは, 底面近傍の 流速分布より対数則から求めた。Sill Typeの各 ケースでは平面形状による影響は顕著であり，ア 一チ型と逆アーチ型では全く異なる分布傾向を示 している。即ちアーチ型では水路中央で集中的に

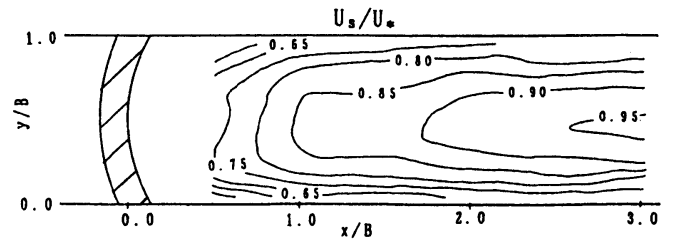

(b) アーチ型 $(S$ i11:R=B)

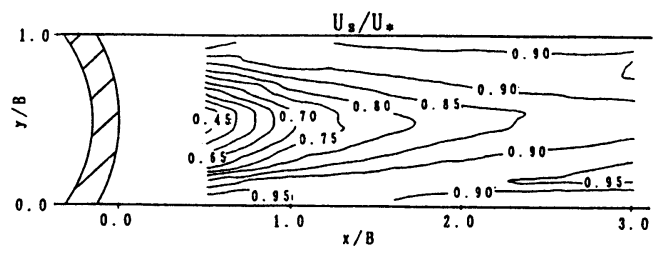

(d) 逆アーチ型 $(S$ i 11: R=B $)$

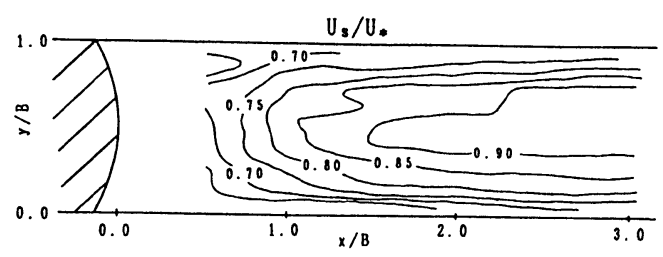

(e) 逆アーチ型 (Backstep:R=B)

図-9 底面せん断力分布 
せん断力が增大しているのに対し, 逆アーチ型では両側壁付近 に向かってせん断力が増大している。また,アーチ型では曲率 半径が小さいほどせん断力分布の集中の程度が增している。一 方, Backstep Typeについては逆アーチ型の結果を図ー9(e)に 示すが, 基本的にはSill Typeのアーチ型と類似した分布形とな っている。Backstep Typeの場合は，他の平面形状においても分 布形に大きな違いはなく，床止め工の平面形状による影響はほ とんどないことがわかる。

図-10は, Sill Typeの場合について側壁付近 $(\mathrm{y} / \mathrm{B}=0.05)$ にお けるせん断力の流下方向への分布を示すが, 各ケースの特徵が よく出ている。流下方向には直線型の值に渐近するように変化 しているが，x/B=3.0においてあ各ケースで差が生じている。

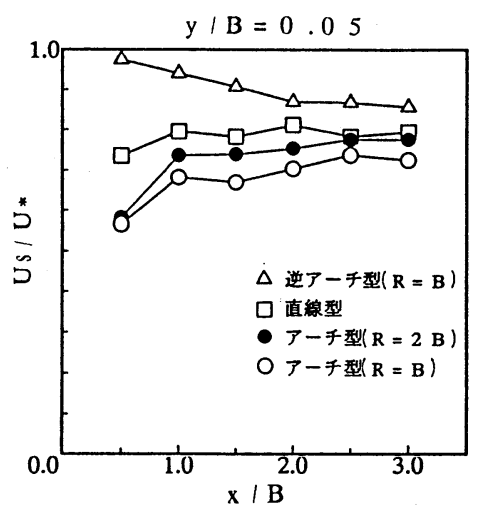

図-10 侧壁付近のせん断力分布の比較

\section{4. 結論}

床止め工の平面形状の違いが流況に与える影響について検討するた めに, 平均流速, 表面流速, 底面流況などの測定を行った結果, 各々 にっいて平均的な流れの構造をある程度把握することができた。図一 11 に流れの構造の推定図を示すが, 床止め工下流の流況にはSi11 Type の床止め工の上流端で剥離した流れの三次元構造が関与していること がわかった。Sill Typeのアーチ型の場合では, 剥離層より上方の流れ が水路中央に集中することにより下降流が生じ, その結果底面せん断 力がその部分で增大するものと考えられる。底面流線が発散傾向を示 すのあこのためであろう。それに対しSil1 Typeの逆アーチ型では,剥 離層上方の流れが発散することによって側壁付近に下降流が集中しそ の部分の流速および底面せん断力が増大する。それにとるなって水路 中央で上昇流が発生するため, 底面流線は収縮傾向を示す。床止め工 上流端が存在しないBackstep Typeで,結果の相違がほとんどないのは， 図ー11に示したような剥離流が生じていないためと考えられる。この

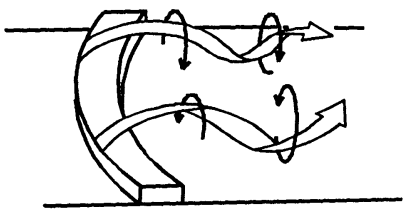

(a) アーチ型

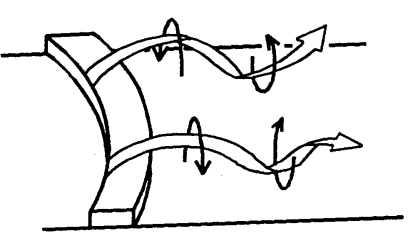

(b) 逆アーチ型

図-11 流れの構造の推定図 ようなアーチ型床止め工を実河川に設置した場合を考えると,設置直後のSi11 Typeの状況では流れの集中に よって河床の洗掘領域が河川中央部に現れるだけでなく，側壁付近での砂州の形成傾向も生じるすのと考え られる。また，十分に堆砂が進行した場合においてもBackstep Typeにおける結果から推定できるように。そ の効果は損なわれないものと思われる。アーチ形状そのものは景観上すぐれており，また，砂州や瀬・淵の 形成は親水性や生態系にとって好ましいと考えられるので, アーチ型化は, 河川構造物として興味深いるの である。しかしながら,アーチ型化によって生じる 2 次流は, その強度が強すぎると従来からの指摘すある ように下流の深掘れなどを誘発する恐れがある。従って今後は, 詳細な乱流計測あるいは移動床実験を行い, 流れの構造およびそれが河床に及ぼす影響についてより詳細に調べていく必要がある。

\section{参考文献}

1 ）松浦茂樹・島谷幸宏 : 水辺空間の魅力と創造, 鹿島出版会, 1987 .

2 ）日本河川協会編：建設省河川砂防技術基準計画編，山海堂，1986.

3 ）藤田一郎・河村三郎・和田賢: 画像計測による開水路直角合流部の表面流況解析, 水工学論文集, Vol. 34, pp. 713-718, 1990. 